\title{
STRATEGI PENGEMBANGAN KAWASAN WISATA DANAU LINOUW DI KOTA TOMOHON PROVINSI SULAWESI UTARA
}

\author{
"LAKE AREA TOURISM DEVELOPMENT STRATEGY LINOUW \\ IN THE CITY OF NORTH SULAWESI PROVINCE TOMOHON"
}

\author{
Darken Tabuni \\ Gene H. M. Kapantouw \\ Leonardo R. Rengkung
}

\begin{abstract}
North Sulawesi in addition to having some of the leading tourist attractions such as Bunaken Marine Park also has the attraction of alternative that still needs to be developed attractions include Lake Linouw in Tomohon. The purpose of this study was to identify appropriate development strategies in the tourist area of Lake Linouw in Tomohon, North Sulawesi. Research method was descriptive methods. Determination of the sample is based on non-probability sampling techniques. Collecting data through pre-survey, survey questionnaires, and study the literature. Data analysis has used SWOT analysis. The results showed that the tourist area of Linouw Lake at Tomohon, North Sulawesi is the growth strategies of concentration through vertical integration or the strategy of Rapid Growth Strategy (strategy of rapid growth). Therefore, it can be concluded that the main strategy to develop the tourist area of Lake Linouw be competitive position is strong and has a high tourist pull. Based on these research results, it is suggested that relevant parties should maintain tourist area Linouw Lake at Tomohon in a competitive position in the strong growth to improve tourist pull high and considering the relatively expensive tourist prices.
\end{abstract}

Keywords: strategy development, tourism, Linouw Lake, SWOT

\section{Abstrak}

Sulawesi Utara selain memiliki beberapa objek wisata unggulan seperti Taman Laut Bunaken juga memiliki objek wisata alternatif yang masih perlu untuk dikembangkan diantaranya adalah objek wisata Danau Linouw di Kota Tomohon. Adapun tujuan dalam penelitian yaitu untuk mengidentifikasi strategi pengembangan yang tepat di kawasan wisata Danau Linouw di Kota Tomohon Sulawesi Utara. Metode penelitian berupa metode deskriptif. Penentuan sampel berdasarkan teknik non-probability sampling. Pengumpulan data melalui pra survey, survey dengan menggunakan kuesioner, dan study pustaka. Analisis data menggunakan analisis SWOT. Hasil penelitian menunjukkan bahwa Kawasan wisata Danau Linouw Tomohon Sulawesi Utara berada pada strategi pertumbuhan konsentrasi melalui integrasi vertikal atau pada strategi Rapid Growth Strategy (strategi pertumbuhan cepat), sehingga dapat disimpulkan bahwa strategi utama untuk mengembangkan kawasan wisata Danau Linouw berada pada posisi kompetitif yang kuat dan memiliki daya Tarik wisata yang tinggi. Berdasarkan hasil penelitian ini, disarankan pihak terkait dapat tetap mempertahankan kawasan wisata danau Linouw Tomohon pada posisi yang kompetitif dalam pertumbuhan yang kuat untuk meningkatkan daya Tarik wisata yang tinggi dan mempertimbangkan harga wisata yang relatif mahal.

Kata Kunci: Strategi pengembangan, Pariwisata, SWOT, Danau Linouw

\section{PENDAHULUAN}

Berkembangnya pariwisata di suatu daerah akan mendatangkan banyak manfaat bagi masyarakat, yakni secara ekonomi, sosial dan budaya. Namun, jika pengembangannya tidak dipersiapkan dan dikelola dengan baik, justru akan menimbulkan berbagai permasalahan yang menyulitkan atau bahkan merugikan masyarakat. Untuk menjamin supaya pariwisata dapat ber- 
kembang secara baik dan berkelanjutan serta mendatangkan manfaat bagi manusia dan meminimalisasi dampak negatif yang mungkin timbul maka pengembangan pariwisata perlu didahului dengan kajian yang mendalam, yakni dengan melakukan penelitian terhadap semua sumber daya pendukungnya (Wardiyanta, 2006).

Sulawesi Utara memiliki beberapa objek wisata unggulan diantaranya yaitu Taman Laut Bunaken yang dikenal sejak lama baik oleh wisatawan lokal, domestik maupun mancanegara. Kota Tomohon juga memiliki berbagai potensi dibidang pariwisata yang tidak kalah bagusnya dengan daerah-daerah lain yang ada di Sulawesi Utara. Khususnya wisata alam Kota Tomohon memiliki sebuah danau yang sudah dikenal sejak dari dulu yaitu Danau Linouw. Danau Linouw merupakan salah satu daya Tarik wisata yang digemari oleh wisatawan mancanegara maupun nasional.

Beberapa ciri khas dan keunikan yang ada pada Danau Linouw yang telah dimaksudkan di atas antara lain yaitu perubahan tiga warna air Danau, lumpur panas, belerang, dan memiliki satwa endemic berupa burung blibis dan serangga yang oleh penduduk setempat dinamakan "sayok" atau "komo". Serangga unik tersebut hidup di air tapi bersayap dan bisa terbang. Keunikan Danau Linouw, dan kenyataan bahwa sudah makin banyak wisatawan baik nusantara maupun mancanegara yang berkunjung ke kawasan wisata Danau Linouw menunjukkan adanya potensi yang lebih besar untuk mengembangkan kawasan wisata Danau Linouw.

Apabila kawasan Danau Linouw dapat dikembangkan lebih baik, maka daya tariknya terhadap wisatawan akan lebih meningkat dengan demikian dapat menjadi salah satu objek akan atraksi wisata andalan Sulawesi Utara dalam meningkatkan kunjungan wisatawan di daerah ini. Adapun tujuan dalam penelitian yaitu untuk mengidentifikasi strategi yang tepat dalam pengembangan kawasan wisata Danau Linouw di Kota Tomohon Sulawesi Utara.

Menurut Sjafrizal (2009 perencanaan pada dasarnya merupakan cara, teknik atau metode untuk mencapai tujuan yang diinginkan secara tepat, terarah dan efisien sesuai dengan sumberdaya yang tersedia. Dengan demikian, secara umum perencanaan pembangunan adalah cara atau teknik untuk mencapai pembangunan secara tepat, terarah dan efisien sesuai dengan kondisi negara atau daerah bersangkutan. Sedangkan tujuan pembangunan pada umumnya adalah untuk mendorong proses pembangunan secara lebih cepat guna mewujudkan masyarakat yang maju, makmur dan sejahtera. Menurut Taringan (2012) mengemukakan bahwa secara sederhana perencanaan adalah menetapkan suatu tujuan dan memilih langkahlangkah yang diperlukan untuk mencapai tujuan tersebut.

Menurut Rustiadi (2011) mengemukakan bahwa secara umum terdapat dua unsur penting dalam perencanaan yaitu hal yang ingin dicapai, dan cara untuk mencapainya. Dalam proses perencanaan, kedua unsur tersebutbaik secara eksplisit maupun implisit dianut pada berbagai nomenklatur seperti visi, misi, tujuan, sasaran, strategi, kebijakan, program, proyek, aktivitas dan lain sebagainya. Perencanaan memiliki ruang dan waktu, sehingga memelurkan penjelasan mengenai fenomena di masa lalu dan yang akan datang, serta distribusinya secara spasial.

Destinasi merupakan suatu tempat yang dikunjungi dengan waktu yang signifikan selama perjalanan seseorang dibandingkan dengan tempat lain yang dilalui selama perjalanan. Destinasi berjalan menurut siklus evolusi yang terdiri dari tahap pengenalan (introduction), pertumbuhan (growth), pendewasaan (maturity), penurunan (decline), dan peremajaan (rejuvenation). Tujuan dari penggunaan model siklus hidup destinai (destination lifecycle model) adalah sebagai alat untuk memahami evoslusi dari produk dan destinasi pariwisata (Butler 1980 dalam Pitana 2009).

Menurut Cochrane dalam Sutiarso (2004) yang memiliki objek wisata alam Bromo-Tengger menyatakan bahwa kegiatan pariwisata alam tidak mungkin secara sendirian dapat mendukung konservasi pada area yang ditargetkan. Dukungan pemerintah dalam perangkat peraturan-peraturan dan insentif masih esensial dilakukan. Berdasarkan penelitian tersebut di atas dapat diambil benang merahnya bahwa pengembangan dan pengelolaan suatu kawasan wisata yaitu khususnya Kawasan Danau Linouw tidak terlepas dari adanya campur 
tangan Pemerintah Kota, Swasta dan melibatkan masyarakat setempat sebagai pendukung pelaksanaan dan tanpa meninggalkan nilai nilai tradisional masyarakat, agar keunikan dan ciri khas kawasan wisata tersebut berbeda dengan tempat yang lain.

Wahyudi (2009) dalam penelitiannya, "Strategi Pengembangan Sungai Sampean Baru Sebagai Daya Tarik Wisata Arung Jeram Di Kota Bondowoso menggunakan strategi pengembangan dengan: Strength Opportunities (SO), yaitu Strategi Pengembangan Produk. Weakness Opportunity (WO), yaitu Strategi Promosi (Pengembangan Pasar Wisata). Weakness Threats (WT), yaitu Strategi Pengembangan Pariwisata Sungai. Strength Threats (ST), adalah Strategi Pengembangan Kelembagaan dan DIKLAT SDM Pariwisata. Penelitian Wahyudi ini mengunakan analisis SWOT. Persamaan penelitian ini terletak pada topiknya yaitu strategi pengembangan sebagai daya tarik wisata dengan analisis SWOT sedangkan perbedaannya pada objek penelitian.

Hasil penelitian Sonder menunjukkan kondisi Pantai Lasiana dilihat berdasarkan prinsip pariwisata berkelajutan dalam pengembangnya belum optimal. Hal tersebut dapat dilihat pada dimensi ekonomi, wisatawan belum merasa puas terhadap pengembangan pariwisata dan pengeluaran mereka belum optimal, sedangkan dari penyedia jasa belum ada distribusi pendapatan yang adil, belum mampu meningkatan kesempatan kerja masyarakat dan baru mampu menambah sedikit peluang usaha bagi masyarakat.

Menurut Nilasari (2014) menyatakan bahwa strategi dibagi berdasarkan tingkatan-tingkatan tertentu. Secara umum tingkatan strategi terbut dibagi menjadi tiga bagian yaitu strategi korporasi, strategi bisnis, dan strategi fungsional. Strategi korporasi lebih ditujukan untuk apa bisnis itu dibuat dan bagimana perushaan harus bertindak untuk mencapai tujuannya. Konsep strategi adalah bagaimana membuat langkah awal suatu perencanaan atau taktik-taktik apa saja yang akan dilakukan dalam merencanakan, merumuskan strategi kebijakan dalam pengelolaan maupun pengembangan kawasan Danau Linouw sebagai daya tarik wisata di Kota Tomohon Provinsi Sulawesi Utara.
Kebijakan (policy) merupakan arah atau tuntunan dalam pelaksanaan suatu kegiatan oleh suatu pemerintah yang diekspresikan dalam sebuah pernyataan umum mengenai tujuan yang ingin dicapai, yang menuntun tindakan dari para pelaksana, baik di pemerintahan maupun di luar pemerintahan, dalam mewujudkan harapan yang telah ditetapkan tersebut. Pengertian kebijakan terdapat penekanan pada koordinasi dari berbagai organisasi dan instansi yang terlibat dalam penyediaan pelayanan, perencanaan, pengembangan, dan manajemen pariwisata. Proses implementasi kebijakan pariwisata memerlukan beberapa tahapan, yaitu: Mengevaluasi potensi pasar, memilih lokasi yang cocok, mengidentifikasi pemain kunci (stakeholders), melakukan studi fisibilitas pasar dan keuangan (Pitana dan Diarta, 2009).

Perencanaan Pengembangan kawasan pariwisata tidak terlepas dari adanya sebuah kebijakan yang dibuat oleh Pemerintah maupun swasta yang berkerjasama untuk membangun dan mengelola tempat wisata sebagai daya tarik wisata yang bertujuan untuk menarik perhatian wisatawan maupun menambah kunjungan wisatawan ke tempat wisata tersebut. Tujuan pengembangan pariwisata tidak lain adalah upaya mendukung baik tujuan pembangunan daerah yang lebih luas maupun tujuan pembangunan nasional, sehingga harus dapat "dibaca" sebagai kebijakan yang saling menunjang.

Kawasan adalah wilayah yang memiliki fungsi utama lindung atau budidaya (Undangundang Nomor 26 Tahun 2007 tentang Penataan Ruang). Lebih lanjut dalam regulasi tersebut dijelaskan maksud daripada wilayah adalah ruang yang merupakan kesatuan geografis beserta segenap unsur terkait yang batas dan sistemnya ditentukan berdasarkan aspek administratif dan/atau aspek fungsional.

Daya tarik wisata yang dimiliki suatu destinasi pariwisata atau daerah tujuan wisata (DTW), yakni sesuatu yang dapat dilihat. Daya tarik wisata adalah segala sesuatu yang memicu seseorang dan/atau sekelompok orang mengunjungi suatu tempat karena sesuatu itu memiliki makna tertentu, misalnya: lingkungan alam, peninggalan 
atau tempat sejarah, peristiwa tertentu (Warpani dan Indira, 2007).

Danau adalah satu bentuk ekosistem yang menempati daerah yang relative kecil pada permukaan bumi dibanding dengan habitat laut dan daratan. Danau Linouw terbentuk akibat gerakan vulkanik, dan merupakan danau terkecil yang terdapat di Provisinsi Sulawesi Utara. Danau Linouw juga merupakan salah satu sumber air panas bagi masyarakat local maupun para wisatawan yang berkunjung di kawasan sekitarnya. Danau Linouw memiliki fungsi yang beragam yaitu selain sebagai penunjang kehidupan manusia juga berfungsi sebagai sumber habitat flora dan fauna endemic, sumber air baku kehidupan, daerah resapan, memelihara kesehimbangan iklim mikro, serta penghasil energy gas bumi.

Permasalahan yang telah dirumuskan, diperlukan kerangka konsep dan atau model penelitian yang dapat dijadikan kerangka kerja di dalam penelitian ini. Alur pikir dari model penelitian ini berawal dari adanya potensi-potensi Danau Linouw sebagai daya Tarik wisata serta ketertarikan wisatawan untuk berkunjung ke Danau Linouw. Berdasaran berbagai macam masalah yang di dapat, secara khusus peneliti ingin mengkaji beberapa permasalahan dengan perumusan masalah seperti, strategi apa yang dikembangkan dalam pengembangan kawasan wisata Danau Linouw di Kota Tomohon Sulawesi Utara?.

Perumusan masalah tersebut akan dikaji dan didasarkan dengan beberapa konsep, teori serta akan dianalisis dengan metode deskriptif dan menggunakan analisis SWOT, setelah itu ditentukan suatu hasil kemudian akan direkomendasikan kepada pihak-pihak terkait terutama pemerintah Kota Tomohon sebagai sumbangan atau masukan pemikiran dalam mengembangkan kawasan wisata Danau Linouw di Kota Tomohon.

\section{METODOLOGI PENELITIAN}

Jenis penelitian menggunakan metode deskriptif dimana data dikumpulkan, dianalisis dan dideskripsikan dengan menggunakan pendekatan kuantitiatif. Penentuan sampel digunakan melalui teknik non-probability sampling yaitu dengan cara aksidental dan purposive sampling. Teknik aksidental yang dimaksud menyangkut teknik penentuan sampel secara kebetulan, sedangakan sampling purposive meliputi teknik penentuan sampel dengan pertimbangan tertentu.

Pengumpulan data dilakukan dengan beberapa tahap yang meliputi pra survey lapangan, kuesioner dan studi pustaka. Pengelolaan data digunakan dengan analisis SWOT (Kekuatan/ Strength, Kelemahan/Weakness, Peluang/Opportunitiess, Ancaman/Treath) untuk mengelola data penelitian.

\section{HASIL PENELITIAN DAN PEMBAHASAN}

\section{Deskripsi Umum Lokasi Penelitian}

Secara astronomis Kota Tomohon terletak diantara $1^{\circ} 15^{\prime}$ Lintang Utara dan 124 $50^{\prime}$ Bujur Timur. Hal ini menunjukkan bahwa lokasi penelitian berada pada daerah yang beriklim tropis dengan memilki dua tepe musim yaitu musim kemarau dan musim penghujan dan terletak pada ketinggian ratarata 700-800 meter dari permukaan laut yang menyebabkan suhu udara sangat sejuk antara $19-29^{\circ} \mathrm{C}$. Luas wilayah Kota Tomohon secara keseluruhan sekitar $147,21 \mathrm{~km}^{2}$

Jumlah penduduk Kota Tomohon secara keluruhan adalah 95157 jiwa dengan ketentuan bahwa laki-laki sebanyak 47898 jiwa dan perempuan sebanyak 46259 jiwa. Mayoritas penduduk Kota Tomohon adalah suku Minahasa dengan sub suku Tombulu namun sebagian juga terdapat sub suku Toutemboan yang mendiami ujung Utara Kota Tomohon yaitu tepatnya di Kelurahan Tinoor yang terdiri dari Tinoor satu dan Tinoor dua. Penduduk lain juga mendiami di Kota Tomohon baik berasal dari suku Minahasa maupun suku lain di Indonesia.

Sejak dulu Tomohon dikenal sebagai Kota pendidikan dan Kota agama atau religius, karena di sinilah para misionaris dari negeri Belanda menetap dan membuka sekolah-sekolah, rumah sakit dan menjadi pusat penyebaran agama Kristen di Tanah Minahasa. Tomohon memiliki fasilitas pendidikan mulai dari Taman Kanak-kanak (TK) hingga perguruan tinggi atau universitas.

Mayoritas masyarakat Kota Tomohon memeluk agama Kristen dan menjadi pusat penyebaran agama Kristen Protestan di Minahasa. Kantor Pusat Sinode Gereja Masehi Injili di Minahasa (GMIM) yang adalah gereja terbesar yang ada di 
Sulawesi Utara, berlokasi di Kota Tomohon. Demikian juga dengan Gereja Katolik Roma yang memiliki banyak pemeluk dengan sejarah yang panjang di Tomohon. Kantor Konferensi Gereja Masehi Advent Hari Ketujuh wilayah Tomohon dan Minahasa Selatan berpusat juga di Tomohon.

Kota Tomohon dikenal sebagai Kota bunga (kembang) karena Tomohon adalah daerah penghasil bunga terbesar di Provinsi Sulawesi Utara dan selain itu Kota Tomohon juga dikenal sebagai salah satu produsen sayur-sayuran dan tanaman hortikultura lainnya. Tidak hanya itu, letaknya yang diapit oleh tiga gunung berapi aktif yaitu gunung Lokon, Mahawu dan gunung Masarang menjadikan wilayah ini sebagai daerah yang subur dan sebagai daerah wisata karena hawanya yang sejuk.

\section{Hasil Analisis SWOT}

Analisis SWOT didasarkan pada logika untuk memaksimalkan kekuatan (Strength) dan peluang (Opportunitiess), namun secara bersamaan dapat meminimalkan Kelemahan (Wekness) dan Ancaman (Treath). Analisis faktor internal dan eksternal dipakai untuk mengetahui kekuatan dan kelemahan, serta mampu mengurangi kelemahan yang ada dan pada saat yang sama memaksimalkan kekuatan. Hal yang sama juga berlaku pada ancaman dan peluang, dimana pada saat ancaman dapat diperkecil, peluang yang ada justru diperbesar. Berikut akan diuraikan analisis terhadap kondisi yang dihadapi dalam mengembangkan kawasan pariwisata di Danau Linouw Kota Tomohon yang meliputi analisis kondisi internal dan analisis kondisi eksternal sebagai berikut.

\section{Analisis Faktor Internal (IFAS)}

Analisis lingkungan internal yang dilakukan yaitu terhadap faktor-faktor strategis internal yang terdiri dari kekuatan dan kelemahan dalam pengembangan kawasan wisata danau Linouw Kota Tamohon.

Berdasarkan hasil análisis faktor strategis internal pada Tabel 1 menunjukkan bahwa skor total hasil análisis internal adalah 2.97 yang menandakan kawasan wisata danau Linouw Tomohon berada pada posisi "sedang" dalam memanfaatkan kekuatan untuk menghadapi kelemahan yang dihadapi dalam pengembangan kawasan wisata danau Linouw Tomohon. Adapun kelemahan utama yang ada pada kawasan wisata danau Linouw Tomohon terletak pada promosi yang belum maksimal dengan skor internal 0.32. Sebagai kawasan wisata yang banyak dikenal oleh masyarakat, harga wisata yang ditawarkan saat ini relatif lebih mahal dibandingkan dengan kawasan wisata lainnya yang ada di Kota Tomohon Sulawesi Utara.

\section{Análisis Faktor Eksternal (EFAS)}

Analisis kondisi eksternall dilakukan terhadap faktor-faktor strategis yang terdiri atas peluang dan ancaman dalam pengembangan kawasan wisata danau Linouw Kota Tamohon. Adapun faktor-faktor strategis eksternal yang dimaksud di lihat pada Tabel 2.

Hasil analisis faktor strategis eksternal melalui peluang dan ancaman mendapat skor total analisis eksternalnya adalah 3.05 yang menandakan bahwa pengembangan kawasan wisata danau Linouw Tomohon berada pada posisi eksternal "kuat" dalam memanfaatkan peluang untuk mengatasi ancaman yang dihadapi. Adapun ancaman utama yang ada pada pengembangan kawasan wisata danau Linouw Tomohon adalah persaingan pariwisata antar objek wisata dengan skor eksternal 0.18 .

\section{Analisis Internal-Eksternal (IE)}

Berdasarkan hasil analisis strategi factor internal dan factor eksternal dapat dimasukkan hasilnya ke dalam matrik internal eksternal sebagai tahap pencocokan strateggi pengembangan kawasan wisata danau Linouw Tomohon. Dari hasil analisis sebelumnya telah didapatkan nilai skor total IFAS adalah 2.97 dan EFAS adalah 3.05. Hasil skor total matrix IFAS tersebut berada pada sumbu $X$ dan skor total dari matrik EFAS berada pada sumbu Y. Skor pembobotan total pada matriks internal eksternal (IE) pada Tabel 2 menunjukkan bahwa kawasan wisata danau Linouw Tomohon berada pada sel I, II, IV yang dapat digambarkan "tumbuh dan berkembang". Hal ini merupakan strategi utama untuk mengembankan kawasan wisata pada posisi kompetitif yang kuat dan memiliki daya Tarik wisata yang tinggi. 
Tabel 1. Matrik IFAS

\begin{tabular}{|c|l|c|c|c|}
\hline No & \multicolumn{1}{|c|}{ Kekuatan } & Bobot & Rating & Skor \\
\hline 1. & Pemandangan alam yang indah, berhawa sejuk dan asri & 0.21 & 3.87 & 0.81 \\
\hline 2. & Objek wisata yang unik dan menarik & 0.18 & 3.73 & 0.67 \\
\hline 3. & Keramahan masyarakat sekitar & 0.08 & 3.00 & 0.24 \\
\hline $4 . \quad \begin{array}{l}\text { Paket wisata yang lengkap dengan beberapa pilihan } \\
\text { fasilitas pendukung }\end{array}$ & 0.05 & 2.13 & 0.11 \\
\hline 5. & Mudah dijangkau & 0.07 & 3.20 & 0.22 \\
\hline Jumlah Kekuatan & 0.59 & & 2.05 \\
\hline \multicolumn{2}{|l|}{} & Bobot & Rating & Skor \\
\hline No & Kelemahan & 0.10 & 1.93 & 0.19 \\
\hline 1. & Kurangnya atraksi wisata & 0.15 & 2.10 & 0.32 \\
\hline 2. & Promosi belum maksimal & 0.05 & 2.00 & 0.10 \\
\hline 3. & Kurangnya toko souvenir & 0.07 & 2.87 & 0.20 \\
\hline 4. $\quad$ Kurang memadai fasilitas pendukung & 0.03 & 3.47 & 0.10 \\
\hline 5. & Kondisi jalan yang sempit & 0.01 & 1.00 & 0.01 \\
\hline 6. & Harga wisata yang relatiff mahal & 0.41 & & 0.92 \\
\hline Jumlah Kelemahan & 1.00 & & 2.97 \\
\hline Total Kekuatan dan Kelemahan & & \\
\hline Skor Kekuatan - Kelemahan = 2.05-0.92=1.13
\end{tabular}

Sumber: Hasil Analisis data IFAS 2015

Tabel 2. Matriks EFAS

\begin{tabular}{|c|c|c|c|c|}
\hline No & Peluang & Bobot & Rating & Skor \\
\hline 1. & $\begin{array}{l}\text { Sektor pariwisata yang semakin berkembang dan } \\
\text { semakin dinikmati }\end{array}$ & 0.15 & 4.00 & 0.58 \\
\hline 2. & $\begin{array}{l}\text { Menyerap tenaga kerja di daerah sekitar objek wisata } \\
\text { yang dapat mengurangi pengangguran }\end{array}$ & 0.06 & 1.80 & 0.11 \\
\hline 3. & Keterlibatan pemerintah dan pihak swasta & 0.12 & 2.67 & 0.32 \\
\hline 4. & Teknologi yang semakin berkembang & 0.40 & 4.00 & 1.59 \\
\hline 5. & Omongan atau opini publik dari wisatawan ke orang lain & 0.04 & 1.73 & 0.08 \\
\hline \multicolumn{2}{|c|}{ Jumlah Peluang } & 0.77 & & 2.68 \\
\hline No & Ancaman & Bobot & Rating & Skor \\
\hline 1 & Persaingan pariwisata antar objek wisata & 0.07 & 2.60 & 0.18 \\
\hline 2 & Terjadinya bencana atau gangguan alam & 0.03 & 1.60 & 0.05 \\
\hline 3 & Pendangkalan danau & 0.13 & 1.07 & 0.14 \\
\hline \multicolumn{2}{|c|}{ Jumlah Ancaman } & 0.23 & & 0.37 \\
\hline \multicolumn{2}{|c|}{ Total Peluang dan Ancaman } & 1.00 & & 3.05 \\
\hline
\end{tabular}

Sumber: Hasil Analisis Data EFAS 2015 


\section{Analisis SWOT}

Dari perhitungan nilai IFAS dan EFAS diperoleh hasil dengan total IFAS adalah 2.97 dan EFAS adalah 3.05, setelah mengetahui kedua nilai tersebut maka dapa disusun diagram analisis SWOT untuk mengetahui posisi relatif kawasan wisata danau Linouw Kota Tomohon pada kuadran pertama, kedua, ketiga atau kuadran kempat. Perhitungan analisis SWOT adalah sebagai berikut:

a. Jumlah dari perkalian bobot dan rating pada opportunity dan shreat diselisihkan untuk mendapatkan titik Y.

$\begin{array}{ll}\text { Opportunity } & =2.68 \\ \text { Threat } & =0.37 \\ \text { Titik Y } & =\text { Opportunity - } \\ \text { Threat } & \\ & =2.68-0.37=\end{array}$

2.31

b. Jumlah dari perkalian bobot dan rating pada strength dan weaknes diselisihkan untuk mendapatkan titik X.

$\begin{array}{ll}\text { Strength } & =2.05 \\ \text { Weaknes } & =0.92 \\ \text { Titik X } & =\text { Strength - } \\ \text { Weaknes } & \\ & =2.05-0.92=\end{array}$

1.13

Hasil perhitungan di atas dapat ditentukan bahwa posisi relatif kawasan wisata danau Linouw berada pada titik kordinat $(1.13 ; 2.31)$ pada kuadran pertama yang menunjukkan bahwa kawasan wisata danau Linouw Tomohon memiliki kekuatan dan peluang sehingga dapat memanfaatkan peluang yang ada dengan menggunakan kekuatan yang dimiliki. Strategi pengembangan yang sesuai dengan posisi kawasan wisata danau Linouw adalah strategi agresif yang mendukung pada pertumbuhan wisata.

\section{Strategi Pengembangan Kawasan Wisata Danau Linouw Tomohon}

Beberapa strategi dasar untuk pengembangan kawasan wisata danau Linouw Tomohon dan secara umum dapat dirumuskan yaitu

1) Menjaga dan melestarikan lingkungan sekitar dengan melakukan penghijauan bersama masyarakat, pemerintah dan pihak swasta.
2) Menigkatkan fasilitas pendukung dengan pihak pemerintah dan swasta.

3) Meningkatkan informasi tentang jangkauan dan jarak tempuh melalui teknologi yang ada dan melalui omongan positif dari wisatawan ke orang lain.

4) Megembangkan atraksi wisata di sektor pariwisata dan melakukan promosi yang berkesinambungan melalui teknologi yang ada

5) Memaksimalkan toko sourvenir melalui masyarakat sekitar untuk meningkatkan pendapatan.

6) Melakukan pelebaran jalan oleh pihak pemerintah dan swasta

7) Mengurangi harga wisata untuk meningkatkan kunjungan wisata.

8) Berusaha memelihara dan melestarikan keragaman alam.

9) Meningkatkan promosi dan pasilitas pendukung.

Dari beberapa uraian di atas menunjukkan bahwa kawasan wisata danau Linouw Tomohon berada pada posisi yang kuat dan berpeluang. Rekomendasi strategi yang diberikan adalah Progresif, artinya kawasan wisata danau Linouw Tomohoni dalam kondisi prima dan mantap sehingga sangat dimungkinkan untuk terus melakukan ekspansi, memperbesar pertumbuhan dan meraih kemajuan secara maksimal.

\section{KESIMPULAN DAN SARAN}

Berdasarkan hasil pengumpulan dan analisis data dapat disimpulkan bahwa strategi pengembangan yang dilakukan di Kawasan wisata danau Linouw Tomohon Sulawesi Utara berada pada strategi pertumbuhan konsentrasi melalui integrasi vertikal atau pada strategi Rapid growth strategy (strategi pertumbuhan cepat). Hasil analisis SWOT dapat menunjukkan bahwa posisi relatif kawasan wisata danau Linouw berada pada kuadran pertama dan memiliki kekuatan dan peluang Strategi pengembangan yang sesuai dengan posisi kawasan wisata danau Linouw adalah strategi progresif yang mendukung pada pertumbuhan. 
Berusaha mempertahankan kawasan wisata danau Linouw Tomohon sebagai posisi yang kompotitif dalam pertumbuhan yang kuat untuk meningkatkan daya Tarik wisata yang tinggi baik wisatawan nasional maupun mancanegara. Meningkatkan promosi melalui teknoologi informasi oleh pemerintah maupun pihak swasta dalam hal ini pemilik atau pengelola kawasan wisata Danau Linouw Tomohon dan mempertimbangkan harga wisata yang relatif mahal. Direkomendasikan bahwa kawasan wisata danau Linouw Tomohon sebagai salah satu alternatif objek wisata andalan Provinsi Sulawesi Utara.

\section{DAFTAR PUSTAKA}

Nilasari. 2014. Manajemen Strategi Itu Gampang. Pariwisata Universitas Udayana Dunia Cerdas. Jakarta Timur.

Pitana dan Diarta. 2009. Pengantar Ilmu Pariwisata. Andi Yogyakarta. Yogyakarta.
Rustiadi. Saeulhakim. \& Panuju. 2011. Perencanaan dan Pengembangan Wilayah. Crestpent Press dan Yayasan Pustaka Obor Indonesia. Jakarta.

Sjafrizal. 2009. Teknik Praktis Penyusunan Rencana Pembangunan Daerah. Baduose Media Kabupaten Boyolali Mei Kuswandari. Dyah Hariani Administarasi Publik Fakultas Ilmu Sosial dan Ilmu Politik Universitas Diponegoro Jl. Tembalang Semarang.

Sutiarso . 2004. Ekowisata Di Taman Nasional

Bromo Tengger Semeru Jawa. Timur; Tesis Kajian Pariwisata Unud.

Taringan. 2012. Perencanaan Pembangunan Wilayah.. Unud Bumi Aksara. Jakarta.

Wahyudi. 2009. "Strategi Pengembangan Sungai Sampean Baru Sebagai Daya Tarik Wisata Arung Jeram Di Kabupaten Bondowoso" (tesis Program Magister Pariwisata). Universitas Udayana. Wisata di Kabupaten Ende Provinsi Nusa Tenggara Timur. Tesis Kajian. Denpasar.

Wardiyanta. 2006). Metode Penelitian Pariwisata. CV Andi. Yogyakarta. 